\title{
The Aristotle of Pippin III. Greek Books Sent to the Frankish Court (ca. 758 AD)
}

\author{
Christian Gastgeber*
}

The article deals with a unique document from the early Carolingian period, a letter from Pope Paul I sent to King Pippin III. An appendix contains a list of books with some Greek works. In this paper the text is critically re-examined from the perspective of the Greek manuscript culture and the intention of this "cultural supplement" to the Frankish court. The text attracted great interest from researchers because the book list also includes works by Aristotle and Ps.Dionysius Areopagite. In recent academic discussions the list was interpreted on the basis of the edition in the Monumenta Germaniae Historica, which claims to be the first real critical edition of the original text in the codex unicus, housed at the Austrian National Library. Some scholars became the victims of earlier editions, which present the text as it was amended in the manuscript itself by the late humanist scholar Sebastian Tengnagel (1563-1636). However, the MGH edition also edits the list as interpreted by the editor (thus presenting an unknown geometry by Dionysius Areopagite), not as the manuscript transmits the text. The grouping of the items in the list is fundamental for interpreting the purpose for which these books were delivered. Hence, this paper goes back to the roots and starts from the manuscript and its punctuation. From a linguistic approach, the Areopagite question appears in a new light, and an Areopagite manuscript, sent to the Franks in around $758 \mathrm{AD}$ - about 70 years before the famous Greek manuscript was handed over by envoys from the Byzantine Emperor - , seems to be responsible for the mistake in the textual transmission. The paper also takes up the question of the quantity of books: in research to date the list was regarded as a small library, but the Greek books listed are rather a comprehensive codex. Finally, the character of the books as analysed here clearly links to a basic introduction to Greek and provokes the question of whether further witnesses of Greek knowledge in the early Carolingian period exist.

Keywords: King Pippin III, Pope Paul I, Greek language, Greek manuscripts, Codex Carolinus, Aristotle, Ps.Dionysius Areopagite, Schoolbooks, Greek letters

* Correspondence details: Christian Gastgeber, Division of Byzantine Studies, Institute for Medieval Research, Austrian Academy of Sciences, Hollandstraße 11-13, 1020 Vienna, Austria. Email: christian.gasteber@oeaw.ac.at. 


\section{Introduction}

We are confronted with a particular case of cultural contact in the period of Pope Paul I (757-767): around $758^{1}$ the Pope sent a few books to Pippin the Short, the first Frankish king of the Carolingian dynasty (751-768). The letter which reports this fact provides further information about the content and language: astonishingly, the Latin pope sent as many Greek books as he could find - I assume in Rome, from his or a local library ${ }^{2}$ - except for a volume by Dionysius the Areopagite, books that can be classified as the fundamental texts for Greek language learning. More than 70 years before the famous, still extant Areopagite manuscript (Paris, Bibliothèque nationale de France, ms. grec 437) ${ }^{3}$ was sent by the Byzantine emperor Michael II in May $827^{4}$ to the emperor Louis the Pious (778-840), one (or more) work(s?) by this author had already been sent to the Frankish court. Hence, with the support of the pope, teaching Greek language (and literature) started some time before the »revival « of Greek in the so-called Carolingian Renaissance of Charlemagne and, remarkably, even the Areopagite manuscript was read and studied long before Hilduin of St. Denis worked on his translation, based on the manuscript recently sent by the Byzantine emperor. But that is not all: these books even included a work by Aristoteles, identification of which has provoked heated debates among modern scholars.

These are the crude facts which demand a deeper analysis of why and which Greek books were sent to the North at that time and how this should be interpreted against the cultural background of the respective language skills. Before I focus on the book list, some words on the letter itself and its transmission are necessary.

\section{Transmission of Pope Paul's letter}

Our text is included in a famous collection of papal letters, the Codex Carolinus, today housed in the Austrian National Library as codex 449, which has been exhaustively studied; ${ }^{5}$ I sum up the essential data as follows: the original codex, possibly the master copy of the Vienna manuscript, was written in 791 by order of Charlemagne and contained all letters from the popes to his grandfather Charles Martel, his father Pippin the Short and to Charlemagne himself. ${ }^{6}$ This Charlemagne codex is not preserved, but a later (direct?) copy from the end

1 Date according to Kehr, Chronologie, 133-134, 156; the editor of the letter in the Monumenta Germaniae Historica, Wilhelm Gundlach, dated (before Kehr's analysis) the letter to the years 758-763.

2 For the discussion about the stock of Greek manuscripts in Rome, see Hack, Codex Carolinus, 2, 830-832. The location of such a library (or libraries) remains unidentified. Since I interpret these books as basic schoolbooks, such a stock is not exclusively confined to a Greek (monastic) community in Rome, but may have been part of the papal library as well after the "Greek period« of popes (see Ekonomou, Byzantine Rome) (admittedly, the sources are silent on the subject of the library stock of that time; see Devreesse, Fonds grec, 2).

3 Among the huge bibliography about this ms. and the translation of Hilduin, see the basic study by Théry, Études Dionysiennes, and recently Erismann, Significance.

4 See Dölger, et al., Regesten 1,1, Reg. 413 (the new identification in the revised second edition of the Regesten with the famous "Kaiserbrief" of St. Denis is not convincing, see below n. 64).

5 See (with further bibliographic references) Hack, Codex Carolinus, 1, 83-90; Orth-Müller, Philologische Studien.

6 This information is provided in the introduction to the collection; see Codex epistolaris, ed. Gundlach, $476=$ ed. Hartmann and Orth-Müller, 32. 
of the 9th c. is, ${ }^{7}$ commissioned and owned by Archbishop Willibert (of Cologne, 870-889). ${ }^{8}$ The codex aroused the interest of the Protestants so that some letters were published in the Magdeburg Centuries (appeared in Basel 1559-1574) of Flacius Illyricus; ${ }^{9}$ it is deemed probable that the transfer to the imperial library in Vienna goes back to Flacius' Viennese collaborator Caspar of Niedbruck and that the codex was incorporated into the imperial library in the middle of the 16 th c. $^{10}$ The next sure indication of the codex's presence in Vienna are the corrections by the second prefect of the imperial library, Sebastian Tengnagel, who emended the text in the codex itself (according to classical Latin standards); these purified variants were then adopted by some editors until Philipp Jaffé (and Wilhelm Gundlach) drew on the codex version and banned Tengnagel's emendations. ${ }^{11}$ Among others who published parts or the entire corpus, the fifth prefect of the imperial library in Vienna, Petrus Lambeck, intended to include an edition of the letters in his Syntagma rerum germanicarum. No prints of this document collection exist, but the Austrian National Library preserves Lambeck's preparatory work in codex 9774.

To sum up: the text of this letter is transmitted in a copy from the end of the 9th c., whose archetype (as a codex) dates back to the end of the 8th c. Starting with Jaffé, the text editors followed the original version in the Vienna codex (and not the emendations of the late humanist scholar Sebastian Tengnagel). However, as regards the punctuation, the editors used the common modern separation of phrase and cola units. This is pivotal in analysing the book list because the editors differ significantly in grouping the items in the list. Some mistakes in the text suggest that this (or, if a manuscript existed between the original and the Vienna copy, already a preceding) scribe was responsible for some changes to the original version.

\section{The text and its editions}

I begin my considerations about the books sent to the North with the presentation of the book list as published in the two critical editions as well as with a diplomatic transcription from the manuscript and its punctuation. In addition, the text is presented with the corrections by Sebastian Tengnagel as well. In this part of the codex the scribe almost exclusively uses an interpunct or mid-dot of varying boldness according to the intensity of the break (the smallest dot is used to separate appositions or the parts of series of words); sometimes the interpunct is combined with a separate comma indicating a stronger break. The scribe of the codex never makes use of a comma alone. The commas which appear in the codex were added by the later corrector Tengnagel, who also transformed interpuncts into commas with a dot-like body.

7 See Bischoff, Katalog 3: Padua-Zwickau, 478-479, no. 7121; the codex is online at the homepage of the Austrian National Library. Retrieved on 27 August 2018: data.onb.ac.at/rep/1001A3E3; a facsimile with introduction and description was published in Unterkircher, Codex epistolaris Carolinus.

8 A note recording the owner is today glued on the inside of the front cover; see also Codicis Carolini epistolae, ed. Jaffé, 2.

9 A copy of the relevant letters is preserved in the second part of codex 27.9 Aug. $2^{\circ}$ of the Herzog August Library in Wolfenbüttel; for a detailed description, see Nürnberger, Bonifatiuslitteratur, 18-29 (for the codex), 29-35 (for Niedbruck).

10 See Nürnberger, Bonifatiuslitteratur, 29-35.

11 See the harsh criticism in Codicis Carolini epistolae, ed. Jaffé, 3, 5; repeated in Codex epistolaris, ed. Gundlach, 469470. 
A remark is necessary concerning the punctuation of the manuscript: it is not the original punctuation as witnessed in contemporary charters, ${ }^{12}$ but a modified one created during the process of copying the papal letters into the Charlemagne codex. The dots and commas do not reveal the original separation of the text cola, but how the scribe or scholar responsible for the (lost) archetype of the Codex Carolinus structured the text. Nevertheless, we gain insight into the reading of the text in the Codex Carolinus and a hundred years earlier under Charlemagne if the Vienna manuscript represents an identical copy, on which I base my analysis.

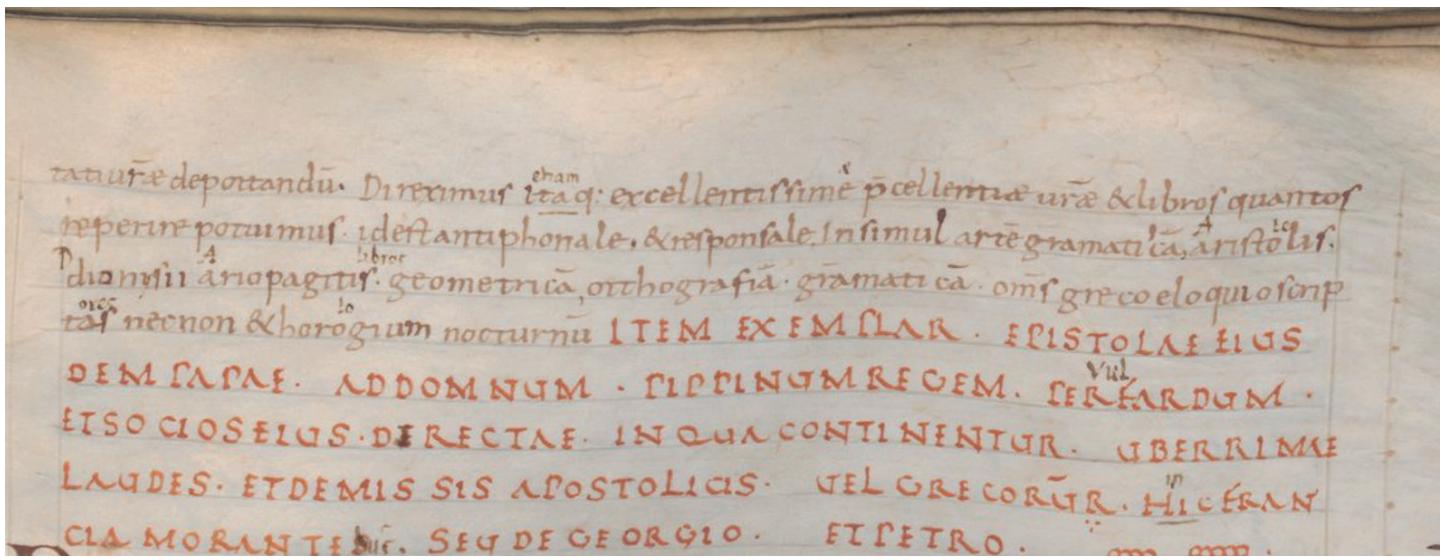

Figure 1: Vienna, Austrian National Library, Cod. 449, f. 36r (part of the embolum) with the corrections by the Viennese librarian Sebastian Tengnagel (c/o ÖNB, Vienna)

Critical edition of the Codex Carolinus by Ph. Jaffé ${ }^{13}$

Direximus itaque excellentissime praecellentiae vestrae et libros, quantos reperire potuimus: id est antiphonale et responsale, insimul artem gramaticam, Aristolis, Dionisii Ariopagitis, geometricam, orthografiam, grammaticam, omnes Greco eloquio scriptas, nec non et horologium ${ }^{2}$ nocturnum.

2) horogium V (= Vindobonensis)

Critical edition of the Codex Carolinus by W. Gundlach ${ }^{14}$ (= recent edition by F. Hartmann and T. B. Orth-Müller ${ }^{15}$ )

Direximus itaque excellentissime praecellentiae vestrae et libros, quantos reperire potuimus: id est antiphonale et responsale, insimul artem gramaticam Aristolis ${ }^{1}$, Dionisii Ariopagitis geometricam, orthografiam, grammaticam, omnes Greco eloquio scriptas, nec non et horologium ${ }^{2}$ nocturnum.

1) an Aristotelis? | 2) horogium V (= Vindobonensis)

12 The oldest preserved original document of the papal chancery dates from 788 (Pope Hadrian I; facsimile in Bruckner and Marichal, Chartae Latinae Antiquiores XVI, 67-71, no. 630), the next one from 11 July 819 (Pope Paschalis I; facsimile in Pontificum Romanorum Diplomata, fig. 1); for the content of the documents cf. Jaffé, et al., Regesta Pontificum Romanorum 2, Reg. 4536 (= JE 2462) and 5031 (= JE 2551).

13 Codicis Carolini epistolae, ed. Jaffé, 99-102 (ep. 24), 101-102 (embolum), 101-102 (list). Critically reviewed by Sickel, Review, and Gundlach, Über den Codex Carolinus (announcing his new critical edition).

14 Codex epistolaris, ed. Gundlach, 527-529 (ep. 24), 529, 11. 9-2 (embolum), 529, 1l. 19-22 (list), critically reviewed by Kehr, Codex epistolaris; reply to this review by Dümmler, Reply.

15 Codex epistolaris Carolinus. ed. Hartmann and Orth-Müller, 162-166 (no. 25 [24]), 164-166 (embolum), 166 (list). 
Diplomatic edition (including punctuation of the manuscript ${ }^{16}$ )

Direximus itaq(ue) excellentissime $p$ (rae)cellentiae $v(e s t) r a e$ (et) libros quantos $\left.\right|^{2}$ reperire potuimus $\cdot$ id est antiphonale $\cdot(?)^{17}$ et responsale Insimul artem gramati..$^{18} \mathrm{ca}(\mathrm{m})$ aristolis $\cdot(?)^{19}$ $1^{3}$ dionysii ariopagitis $\cdot$ geometrica $(m)$ orthografia $(m) \cdot \operatorname{gramatica}(m) \cdot o m(n e)$ s greco eloquio scrip| ${ }^{4}$ tas necnon (et) horogium ${ }^{20}$ nocturnu $(m)$

\section{Corrections by Tengnagel}

Direximus etiam excellentissimae praecellentiae vestrae et libros quantos $\left.\right|^{2}$ reperire potuimus ' id est antiphonale' et responsale, Insimul artem gramati\{.\}cam, Aristotelis, $\left.\right|^{3}$ Dionysii Ariopagitis libros $\cdot$ geometricam, orthografiam $\cdot$ gramaticam $\cdot$ omnes greco eloquio scrip $\left.\right|^{4}$ tores necnon et horologium nocturnum

The critical editions, compared with the original text, already hint at the main problem in interpreting the book list: do the two authors Aristotle and Dionysius Areopagite in the genitive have to be combined with the preceding and following nouns respectively, or are they separate units in this list? Jaffé did not accept that a grammar by Aristotle and a geometry by Dionysius Areopagite - both texts that are not witnessed by any source - separated the authors from the surrounding nouns and made them into items in their own right. The next editor, Gundlach, who intended to amend Jaffés edition, accepted neither the manuscript punctuation nor Jaffé's one; he separated the controversial items into Aristotle's grammar and Dionysius' geometry, and so did the recent editors and translators Hartmann and OrthMüller. ${ }^{21}$ Tengnagel provided the first respective corrections in order to heal the passage: he separated Aristotle from the preceding grammar and added the related accusative libros (depending on direximus). With this addition, he solved the problem of unknown works by the two authors. However, it is the interpretation of a modern scholar who could not cope with the transmitted text and changed it until it appeared reasonable to him. Subsequent scholars preferred Tengnagel's emendation and thus eclipsed the question of unknown works by Aristotle and Dionysius Areopagite. ${ }^{22}$

16 Vienna, Austrian National Library, cod. 449, ff. 35r-36r (embolum: ff. 35v-36r, list: 36r).

17 The dot after antiphonale is bolder than the other separators, and it seems to be shaped (or re-shaped) like a comma, which the original scribe does not use. It cannot be excluded that the original text may have had a small dot here and that Tengnagel wanted to stress the unit by making the dot a bit bolder and shaping it like a comma.

18 Between $i$ and $c$ the original scribe started in the upper part of the space between the lines with a small hook and led the pen to the middle of the interspace, where he stopped, slightly inclining to the left. In comparison to the letters of this scribe, this shape resembles the upper part of the letter $l$ or-less probable $-b$. The scribe does not use any abbreviation identical to this shape. He also was not inclined to correct or cancel this half-letter. Maybe he intended to write gramaticalem

19 Again, this dot seems to be the result of Tengnagel's re-shaping like the dot after antiphonale.

20 The shape of this "m« differs slightly from the other ones by this scribe; it seems that the scribe carelessly started to shape the letter and tried to reshape it as the letter "m«, it is the only letter that he placed significantly over the ground line.

21 Orth-Müller already in the same translation of her printed thesis Philologische Studien, 256-257 (as Cod. Carol. 24).

22 The passage is discussed in detail by referring to all interpretations until 2007 in Hack, Codex Carolinus, 2, 827839. 
We are therefore confronted with a big mystery: if we accept the version of the manuscript, hitherto unknown works by Aristotle and Dionysius Areopagite found their way from Rome to the North, and, evidently, subsequently disappeared. As regards Aristotle, a modification of the name, i.e. the correction of a mistakenly read name or word in the master copy, is not convincing; ${ }^{23}$ if the original text contained a Greek word like APICTO $\Lambda$ IC written in the usual majuscule (Greek) letters, none of the possible similarly shaped variants (A $\triangle \Lambda \mathrm{MN}, \mathrm{EC}$,

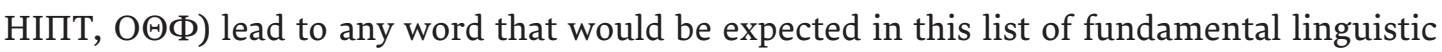
texts, as I interpret the passage.

I will approach the problem through a micro-analysis of the debated passage. The list seems to be divided into three parts: first two liturgical books, then, as a separate unit, the other ones; the "separator is insimul. At the end of the second unit we get the information that all these books were written in Greek. However, this note refers to feminine nouns (scriptas), the only possible reference word must be artes which is used in the singular for the first item and included in the last feminine words (geometricam, orthografiam, grammaticam) as well. ${ }^{24}$ Theoretically, the first unit of the liturgical books may (but, a priori, need not) be included in this omnes note, but modern theological studies back the separation of the two liturgical books into a separate unit, written in Latin. ${ }^{25}$

The last of the three list parts, separated by the strong conjunction necnon et, is the noteworthy horogium nocturnum which was discussed in detail by Achim Thomas Hack in his monograph about the Codex Carolinus. ${ }^{26}$ One would expect here, too, a book, a nocturnale, but in contemporary and earlier sources the word unambiguously refers to a kind of watch, usually operated by means of the sunlight ${ }^{27}$. If this item represents a book list, we expect a liturgical nocturnale to be included in the first part of the list (antiphonale, responsale) and not as an appendix to the artes. Its position at the end of the list and its separation from the Greek unit suggest that this item, if really a book, was not written in Greek. Since it is not added to the theological-liturgical first part of the list and it is named by a term that is not pointed out as differing from the usual meaning »clock «, I am strongly inclined to regard it not as a book, but rather as a further (ordered?) "gift", and to understand nec non et as a strong separator from the preceding libri units.

23 See the proposal by Pierre Riché, discussed in Hack, Codex Carolinus, 2, 828.

24 Interpreted in this way by Sansterre, Moines grecs 1, 182-183. He also divided the passage into three parts as presented in this article.

25 See the respective literature mentioned by Hack, Codex Carolinus, 2, 830.

26 Hack, Codex Carolinus, 2, 833-846, who prefers the interpretation of a book of hours at the end of this book list.

27 See, for example, the explanation in Isidore's Etymologiae XX 13, 5 (horologia, quod ibi horas legamus, id est colligamus; est enim in solariis positum, ubi a clauo per lineas currit umbra, ut quamcumque diei horam ostendat). 
We thus get the following units, according to the manuscript:

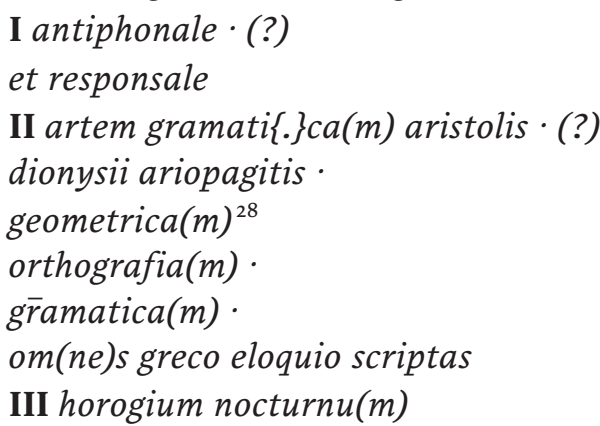

It was primarily the Ariopagite text that aroused interest among scholars. In his study about the history of the works of Ps. Dionysius Areopagite, Gabriel Théry had to deal with this passage. He too accepted Tengnagel's corrections and advocated for the addition of a comma between Ariopagitis et geometricam in order to distinguish them as two separate items. He was not aware that the Vienna manuscript already separated the units in exactly that way. According to him, the Corpus Dionysiacum, "en partie ou dans sa totalité is meant, but there is no evidence of any reception of (these) this work(s). ${ }^{29}$ But if works by Ps. Dionysius Areopagite were really sent to Pippin at his request, was he then suddenly so disinterested in the subject that he put them away, leaving local scholars half a century later unable to find the works of the author they started to glorify? A Greek volume is something extraordinary and exclusive in a North European medieval library stock, wherever the codex was put. It is hard to believe that when people began to worship Dionysius such a unique manuscript fell into oblivion or was even already destroyed. Furthermore, it is astonishing that such a text was ordered and did not leave any marks in the contemporary Latin literature until the Byzantine Emperor's gift. It is, rather, the mention of Dionysius Areopagite in this text that must be examined critically, and I want to propose another solution to this problem without assuming that a Dionysius manuscript was ordered and disappeared.

To return to the manuscript, the scribe of this letter was obviously not familiar with the name Aristotle (Aristolis instead of Aristotelis), if this word was in fact written in the original letter, but he appears to have had no problems with the name Dionysius Areopagite besides the phonetic variant of ario- instead of areo- (which, however, is also witnessed in other authors starting with Cicero, ad Atticum 1, 16, 5; 5, 11, 6 etc.). It is also probable that the vowel $i$ is due to an acoustic confusion with or assimilation to the preceding syllable aris(tolis). The opposite seems to have happened with Aristotle: the scribe did not know this author's name and/or obviously was not able to clearly read or understand it in his master copy, but he did not have any alternative homonym name at his disposal which he could use to replace this word. Therefore, he copied what he could read. As regards Ariopagite, I will come back to the problem below and present another solution.

28 If the scribe consequently separated the text by mid-dots, we would expect punctuation here too; it remains speculative why he omitted the mid-dot, but definitely not to represent a unit.

29 Théry, Études Dionysiennes, 2-3. 
The sequence of the items of the second part of the list and the content is an enigma with regard to the intention behind supplying these books. The list starts and ends with a grammar; in between an orthography is listed. Such books characterise the list as a stock of elementary handbooks for learning Greek. These works make sense if the purpose was the teaching/learning of Greek, fostered by King Pippin - a fact that is witnessed to only by this letter. However, two works absolutely do not match the character of a list of elementary introductions to the language: Dionysius Areopagite and the geometry. To elucidate the problem by a comparable example: if we want to learn Arabic and ask somebody who has access to Arabic books to send us elementary introductions, we will be puzzled by receiving, in addition to a grammar and an orthography, a handbook of mathematics and geometry as well as the works of Naguib Mahfouz, all written in Arabic.

I want to focus first on the geometry: a possible solution to explain its place in this series of elementary school books emerges if we simply separate the first syllable geo and get metricam, which is part of the grammar and trivium basics ${ }^{30}$ as we can see, for example, in the respective schoolbook corpus of Beda Venerabilis (672/3-735), which also includes a handbook about orthography and metrics (De orthographia, De arte metrica et de schematibus et tropis).

This leaves us with the syllable geo- before metricam. Admittedly, this is a hard nut to crack. Our proposal starts from the script of the letter, i. e. the script of the Roman curia, ${ }^{31}$ and similarly shaped letters. In addition, we have to take into account what the introductory preface to the Codex Carolinus reports about the state of preservation of the copied texts: $u t$ universas epistolas ... , eo quod nimia vetustatae et per incuriam iam ex parte diruta atque deleta conspexerat (sc. Charlemagne), denuo memoralibus membranis summo cum certamine renovare ac rescribere decrevit. ${ }^{32}$ In other words, the original papal letters written on papyrus were badly preserved. Hence, if we consider that some letters and syllables could not be read well and look for letters that resemble each other in the Roman curia script, ${ }^{33} g$ and $q$ are noteworthy as they are shaped like the digit $3 ; q$ is, however, bigger than $g$. In such a shape the letters may have caused the misreading of an original syllable que, because $e$ is often ligated to its surrounding letters, that may induce a scribe - nota bene from an original in a bad state of preservation - to mistakenly read the conjunction que as geo (possibly, the original had atque, the difference concerns only the grouping of the unit into either Aristotelis Dionysiique ... or Dionysii atque metricam ...).

30 See, e. g., the definition by Isidore in Etymologiae I 5, 4: Diuisiones autem grammaticae artis a quibusdam triginta dinumerantur, id est, partes orationis octo: uox articulata, littera, syllaba, pedes, accentus, positurae, notae, orthographia, analogia, etymologia, glossae, differentiae, barbarismi, soloecismi, uitia, metaplasmi, schemata, tropi, prosa, metra, fabulae, historiae.

31 The oldest extant originals date from 788 and 828 , see above n. 12 .

32 Codex epistolaris, ed. Gundlach, 476, 1l. 8-15 = ed. Hartmann and Orth-Müller, 32.

33 See the palaeographic analysis of the development of the script in Rabikauskas, Römische Kuriale. 
As outlined in our example of learning Arabic, Dionysius Ariopagite too does not match this series of works, but only the topographic surname; the "first name « Dionysii makes good sense in this list if we interpret him as the famous Greek grammarian Dionysius Thrax (2nd c. BC) whose techne grammatike became a standard schoolbook of Greek grammar (with a considerable manuscript tradition and several comments ${ }^{34}$ ).

If I am right in my approach to the problematic words, the »inappropriate Ariopagitis needs an explanation. In the list the name Ariopagitis is declined like a word in the third declension instead of the Latinised genitive ending -gitae (for Greek -ítnৎ nom., -ítou gen.), the usual genitive ending (or -gite) in mediaeval Latin texts; the name is well known from the passage in the Acts of the Apostles (17, 34: quidam vero viri adherentes ei crediderunt in quibus et Dionisius Ariopagita et mulier nomine Damaris et alii cum eis). It is striking enough that in this list, where the case endings are correct, only the problematic Ariopagitis ends in a "wrong" case. We could interpret it as assonance to the previously mentioned Aristolis, but another solution seems to be more convincing: Ariopagitis may rather be the form of the Greek nominative Apвопаүítnৎ/Areopagitis (Ario- instead of Areo- as a linguistic variation) by spelling the Greek ending -nৎ/ês/ as an iotacistic -is). However, I already pointed out that a nominative does not fit the list of accusative nouns, but it could have been taken into the text from an original marginal or supralinear note to Dionysii whom I identify as Dionysius Thrax. This Thracian Dionysius was surely unknown to the Franks, so that somebody noted in the margin or over the word his presumed identification with Dionysius Areopagite. As an additional note the case need not be adapted to the accusative endings in the text, it was sufficient to explain the name in the nominative case. However, if a reader/commenter added the toponymical attribute in the Greek nominative, this could only happen after the Franks had become familiar with the Greek name, in other words after his worship was fostered by Hilduin and the Franks got the Greek codex in the embassy of $827 .{ }^{35}$ At that time, a scholarly reader / commenter may easily be misled and identify the recently glorified Dionysius with the Dionysius of the list. To sum up our solution of the Dionysius problem: the original papal letter did not contain Ariopagitis, but it was added in the Codex Carolinus by a later annotator after about $827 \mathrm{CE}$.

Two further items in the book list need explanations: Aristotle and the orthography. As just outlined, some researchers tried to solve the Aristotle problem (i.e. a grammar by Aristotle, not witnessed in any source) by separating the unit artem gramaticam Aristolis into an ars grammatica and one (or more) book(s) by Aristotle of whatever content and relating the genitive with the preceding introducing libros - after some items in the accusative. A quick look at items listed in medieval library catalogues ${ }^{36}$ does not contribute to a solution in our case: either liber, expositio (or whatever kind of literature is meant) is added to the author's name (in the genitive) or the author alone is listed in a non-genitive case.

34 Papyrus witnesses since the 2nd c. AD, see the updated Leuven Database of Ancient Books (LDAB numbers 797, 798, 2412, 5969, 7989), co-ordinated by Willy Clarysse. Retrieved on 11 September 2018: www.trismegistos.org/ldab/ index.php. On the author, see also Dickey, Scholarship, 77-80; for the manuscript tradition and reception (the turning point of the supremacy of Dionysius' work among Greek grammars is around the 9th century) see Ronconi, Quelle grammaire.

35 See above, n. 4.

36 For a first overview, see Becker, Catalogi; Pope Paul's letter is included in this collection as no. 2 (p. 2). 
In the critical edition above, it is suggested that the scribe was slightly hesitant in writing gramaticam: after $i$ he seems to have started with a letter in the upper interlinear space. This may be interpreted as a scribal error corrected in scribendo, or he really read something else in the master copy and transformed the word into a common term. Adhering to the punctuation of the Vienna manuscript, I approach the question from the other side, i.e. the author and a work that can be linked to the attribute "gram(m)aticus" or "gram(m)aticalis", possibly in a broader sense. Jean Irigoin was inclined to understand artem gramaticam Aristolis as a real work by Aristotle that is to be counted among basic schoolbooks, ars rhetorica. ${ }^{37}$ But it is rather unlikely that a Latin student wanted to start learning Greek with an introduction to rhetoric, he had Latin ones which were adapted to his language. Furthermore, the interest of the Frankish king was undoubtedly not directed towards Greek literary production, a point I will come back to below when I will discuss the reason for Pippin's interest. A suggestion that combines basic schoolbooks and some linguistic content is Aristotle's De interpretatione or even the more philosophical Categoriae about correct ontological distinctions (but the work already existed in Latin through the translations of Pseudo-Augustinus and Boethius ${ }^{38}$ ). De interpretatione fits the list of works insofar as the works treat the fundaments of language, although the text itself challenges a medieval as well as a modern reader, despite its brevity. But Boethius' translation and its reception witness that this text actually attracted the interest of Western scholars ${ }^{39}$. Admittedly, it is more than an introduction to the language, but it provides the means to correctly use the linguistic basics and it really belonged to the basics in Greek (higher) education, which is convincingly documented by nearly 90 manuscripts from the Byzantine period ${ }^{40}$. Nevertheless, even the advocates of separating the ars gramatica from Aristotle must find a work or corpus that will match the needs of Frankish "students " of the Greek language. Our proposal tries to respect the kommata distribution in the Aristotle unit as transmitted in the codex.

A further argument to strengthen the proposed one list item of the author's name and his work is the order of the list itself. If the Pope did not arrange the list of Graeca randomly, he must have followed a system; it might be to start with works whose authors were worth mentioning and to continue with more or less anonymous works. If we separate the name Aristotle from the work ars gramatica, we face another problem: why did the Pope not combine the two grammars and instead both start and end his list with a grammar? In that order, the list gives a chaotic impression.

The orthography which is listed without a name may be identified with the most popular schoolbook of this content, Herodian's De orthographia (ca. 180-250 AD) or rather a compilation; subsequent grammarians abridged (or excerpted from) his work and created new handbooks, among them, for example, John Philoponus (6th c.) or John Charax (6th c.). However, only fragments of all these works exist. ${ }^{41}$

37 Irigoin, Culture grecque, 426.

38 For Boethius see Cameron, Boethius; Boethius' translation gradually replaced the Pseudo-Augustinus version after the 1oth century, see the chapter "Boethius' Influence in the Middle Ages" in Marenbon, Boethius, 164-182, esp. 165 .

39 On the reception (starting in the 9th century), see Marenbon, Boethius, 165.

40 A constantly updated overview of the Greek manuscripts is provided by the database Pinakes of the CNRS, Paris. 41 See the overview in Hunger, Hochsprachliche profane Literatur, 2, 18-22. 
As far as I am aware, one question was never raised in the scholarly discussion: were the Greek Libri separate physical book units (codices) or did one codex (maybe two codices) comprise them all? The question is certainly justified if we consider that the short works by Dionysius Thrax, Aristotle's De interpretatione, and the metrical handbook will be rather a soft introduction than a detailed study ${ }^{42}$ because the latter would have created great problems as it is based on quotations from classical Greek literature a Frankish beginner could not understand.$^{43}$ Hence, these apparent basic schoolbooks are to be interpreted not as a collection of codices, but rather as a comprehensive introduction to the Greek language containing some texts of various content in one codex. In this regard we have to query the "large selection of Greek manuscripts« sent to Pippin III as scholars have interpreted the passage to date. ${ }^{44}$

A codex of collected works consequently leads to a new interpretation of a much debated phrase in the letter: if the second part of the list, the "Greek" section, was indeed only one comprehensive Greek introductory codex (or two), »direximus ... libros, quantos reperire potuimus « appears in a new light: it cannot mean that the Pope sent as many codices as he could find, but "copies of as many books as we could find « and sent them [in one codex, or two]. Hence, it seems that these books were copied in Rome and that the master copies remained there - which is easier to believe than that the Pope emptied "his" or any other library in Rome. ${ }^{45}$

But it is striking that just one of the most important books for beginners of a new language is missing: a glossary. Moreover, all these introductions are not basics for Latin speakers to learn Greek with a Latin introduction, but with a text in the target language. Automatically, the question arises of how such texts could be understood by beginners. If we come back to our example of learning Arabic, nobody could profit from an Arabic introduction to the language. If this delivery is to make any sense - and was requested by the King himself, as I will show in the next paragraph - the Greek books are not used to initiate learning Greek, but continue what existed already, on whatever level.

\section{The book list in the context of the letter}

The letter whose embolum ends with this book list (and a clock?) does not explain why these codices were sent to Pippin, i.e. if they were ordered or sent on somebody's initiative. Therefore scholars have argued for and against a request from the King, and the provenience of these Greek manuscripts which were at the Pope's disposal was also controversially discussed. ${ }^{46}$ Since a clear indication is lacking, this discussion remains open; it is not the intention of this paper to find the final solution because we have to admit that, on the basis

42 A possible candidate might be the compiled schoolbook of the Alexandrian grammarian Hephaestion (2nd c. AD), his handbook De metris; for an overview of metrical handbooks, see Hunger, Hochsprachliche profane Literatur, 2, 50-54.

43 Cf. the characterisation of the anonymous »barbarian« translator of a chronological handbook by Richard Burgess below, to $\mathrm{n} .77$.

44 See a. o. recently Burgess, Date, 29; in note 72 he tries to heal the text of the debated passage as follows: insimul artem gramaticam, Arist<ot>olis (sic) <et $>$ Dionisii Ariopagitis <opera $>$, geometricam, ... .

45 For the discussion on the place where the books were taken from, see Hack, Codex Carolinus, 2, 830-832.

46 See the overview in Hack, Codex Carolinus, 2, 830-832. 
of our knowledge, absolute certainty cannot be attained, only a hypothetical approach. Nevertheless, the interpretations did not take into account the adverb that links the list to the preceding sentence: itaque. In the conspectus of the editions above it is highlighted that Sebastian Tengnagel tried to emend the adverb by replacing it with etiam. The recent German translation solved the problem by simply dismissing this adverb. ${ }^{47}$

The immediately preceding chapter of the embolum deals with an earlier letter from King Pippin to the Pope, requesting the latter to grant the titulus protectoris vestri, beati Christi martyris Chrysogoni cum omnibus sibi pertinentibus (= the Church S. Crisogono in Rome, Trastevere) to the papal envoy, the presbyter Marinus ${ }^{48}$ (quatenus ... concedere deberemus). The Pope was asked to send a respective praeceptum to the King, complied with his request and sent the praeceptum together with the envoy of this letter to the King. Consequently, Marinus must have received the titulus and the benefices of this sinecure.

In the same letter itaque is used twice and here its meaning is causal as well as consecutive: 1) due to the King's commitment to the church the Pope encourages him to stick to the request of his predecessor, Pope Stephen II (peto itaque et deprecor te..${ }^{49}$ ). 2) At the end of the letter itaque introduces the salutatio after having praised the King's promise to St. Peter: salutant itaque communem excellentiae vestrae christianitatem cuncti sacerdotes et clerus istius sacrosanctae catholicae et apostolicae Romanae ecclesiae ....$^{50}$ The adverb itaque causally links the salutatio to the King's honourable sincerity as well. In other words, the drafter of the letter intentionally employed the adverb to express a consequence from a preceding sentence or chapter.

However, no matter which way you look at it, it is impossible to link the book list to the preceding chapter about the grant of the titulus Chrysogoni so that itaque would make any sense. Neither the alia epistola with Pippin's request nor the Pope's concession refer to the book list in any way so that a causal-consecutive consequence can be derived. But a look at the manuscript may provide a possible solution to this enigma: the sentence direximus itaque starts on a new page (f. 36r) after the words (of the first part of the embolum) ... per arum (sic; sc. litterarum) latorem direximus eximien $\mid{ }^{36 r}$ tati (sic) vestrae deportandum (sc. praeceptum). ${ }^{51}$ After deportandum a bold mid-dot is placed to stress the end of the sentence. We are surely right to assume that the scribe read his master copy in units he could memorise well; generally, such units will correspond to phrases or syntactical-logical cola (membra). Without any doubt, he started a new unit with direximus itaque, but meanwhile his writing position has slightly changed as he began to write on the right page (recto) of the open codex.

47 Codex epistolaris Carolinus, ed. Hartmann and Orth-Müller, 167, reproducing the translation of Orth-Müller, Philologische Studien, 256.

48 On him, see Hack, Codex Carolinus, 1, 479-481; 2, 1011-1012. The Pope's attitude towards him is oscillating during this time, starting positively and then changing as the cleric conspired with the Byzantine emperor's envoy against the Pope and Pippin; see furthermore the entry Marinos (interpreted as a Greek) in Lilie, et al., Prosopographie, online-version \#4803,1. Retrieved on 29 August 2018: www.degruyter.com/view/PMBZ/PMBZ15973.

49 Codex epistolaris, ed. Gundlach, 528, l. 32; Codex epistolaris Carolinus, ed. Hartmann and Orth-Müller, 164.

50 Codex epistolaris, ed. Gundlach, 529, 11. 3-4.

51 Codex epistolaris, ed. Gundlach, 529, 1l. 17-19. 
When he then turned back to his master copy he possibly failed to continue exactly at the end of the unit he had last read and slipped to the end of the following unit, which was marked by a bold dot as well (a homoioteleuton could have caused such an aberration as well). The result is that the Vindobonensis omits a sentence which logically connects the titulus Chrysogoni paragraph to the book list so that itaque makes sense in its usual meaning, i.e. expressing a causal consequence. The omitted sentence must have contained an additional request for books the King asked the Pope to send.

If we accept such an omission, it will help to interpret the text from three aspects:

1) the sequence of the sentences in the Vindobonensis is somehow awkward due to the immediate repetition of direximus: direximus eximie\{n\}tati vestrae deportandum. Direximus itaque excellentissime pracellentiae vestrae ...;

2) itaque would match the logical sequence of the text if a clarifying sentence introduces the book list with reference to the request from the King (in the same alia epistola?);

3) libros, quantos reperire potuimus needs an explanation, because from this phrase one gets the impression that the Pope sent all the books he could find (in his library?). The question automatically arises: a quantity of what? An introductory sentence might therefore have concretised the requested books; for the second "Greek" list unit we assume something like »basic Greek literature» or »elementary Greek books«. Raymond-Joseph Loenertz already advocated a »liste des sdesiderata envoyée par Pépin" in his article about the start of the worship of Dionysius Areopagite by the Franks. ${ }^{52}$

Another solution to heal the text - though in my opinion less convincing - is the emendation of the particle itaque. Looking for a resembling or similarly sounding word (at least in one syllable) that might have confused a scribe, we come upon item. Tengnagel's reading already went in this direction when he annotated itaque with his etiam. Item would link the direximus of this sentence to the preceding one, meaning "we also sent as many books ... to your excellency as well (as you getting the praeceptum)«. Besides the word order direximus item ${ }^{53}$ and the arguments mentioned above, based on which I rather incline towards the omission of a clarifying sentence, two critical points remain: item and et (libros) are somehow redundant. With this emendation, we get rid of the causal consequence, but the list still follows the praeceptum without any obvious connection. The praeceptum is well explained, the list by no means.

52 Loenertz, Légende, 236 (repr.: 181); see also Hack, Codex Carolinus, 2, 832.

53 In this word order the object of comparison is the King, excellentissimae praecellentiae vestrae. But why should the fact of sending some gifts of books to the King be stressed in this way? To whom else should the Pope send the books with his envoy? item would rather make sense if another person was addressed before, but it is to the Kingthat the praeceptum is handed over. 
Greek books: palaeography, codicology, and the target user

To elucidate the problem of reading a Greek manuscript that was addressed above, we have to consider what it meant for a contemporary reader to use a Greek manuscript. In the 8th c. the texts were still written in majuscule letters $;{ }^{54}$ of the different majuscule scripts used at that time the text was very probably written in the usual script for non-theological texts, in the so called maiuscola ogivale (inclinata or diritta) ${ }^{55}$ - unless Rome at that time preferred another majuscule (since I assume that it was here the works were copied). The thinner and bolder parts of the similarly shaped letters easily cause confusion if somebody is not experienced in the language. Even more problematic is the text layout itself: Greek texts at that time were written in scriptura continua without spaces between the words, they were neither accentuated or marked with a spiritus nor distributed in reading units by punctuation. Reading was a process that needed educated and trained lectors. From the text itself, one does not get any support in how to group the words; adverbial particles help to provide a rough structure for the sentences to some degree, but nothing more. Furthermore, changes in the spelling of some consonants and vowels left their traces in orthographic variations. In other words: to read a Greek text from a manuscript and to understand it, meant already having basic knowledge and experience of the language.

This leads us back to the point I addressed above: the target audience of the works. We may sum up the data as follows: the user of the Greek books had already been introduced to the language, at least to the basics, and could read a text in scriptura continua without accents and punctuation; he obviously had a glossary or some kind of dictionary to understand the Greek words. Via the King, he asked for some basic Greek texts. Such a profile points to somebody who knew Greek at whatever level and had an audience of interested students. However, I have to underline - at least at the present stage of research - that we do not know how far back in the preceding period this interest reached. New results are to be expected from the recently intensified and amended research on bilingual palimpsests, in our case with a lower Greek script. The main sources have already been addressed by Walter Berschin in his study about Greek letters in the Latin Middle Ages. ${ }^{56}$ With this opus magistrale the door was opened to more intensive research about the influence of Greek in the West. A very promising path was the study by Bernice M. Kaczynski on a group of Carolingian Latin manuscripts in St. Gall and their traces of Greek language. ${ }^{57}$ An examination of all Merovingian and early Carolingian manuscripts with regard to Greek script traces - including probationes pennae on the endpaper or in the codex margins, Greek words used by Latin authors in their texts and how scribes copied them or particular texts like Greek alphabets, word lists etc. will complete our image of the knowledge at that time, a task that has yet to be undertaken.

54 Whether the books were taken from an existing collection or copied anew for the King, in both cases the script was a majuscule.

55 On this script, see Orsini, Maiuscola ogivale inclinata (with further literature). See also on this script family Crisci, Maiuscola ogivale diritta.

56 Berschin, Greek Letters, 102-125 (Merovingian Gaul and the Carolingian Courts).

57 Kaczynski, Greek. 
Why learn Greek in the Frankish kingdom?

If our argumentation is right, this list confronts us with the intention of the Frankish king to be supported by the Pope in teaching some Franks Greek or at least having some Franks at his disposal who could understand Greek. Was Greek in the Western region, and in the Frankish kingdom in particular, so important that a king needed some bilingual experts, as the King's request seems to suggest? Unfortunately, this and other texts from that time provide no information about the background of such a "cultural innovation«. However, with regard to the need for this language supplement at least two areas of interest can be put forward: diplomatic contact with the Byzantine emperor and Greek literature that was of any interest. ${ }^{58}$

As regards the diplomatic aspect, with Pippin the Franks entered the official stage of the western rulers that were addressed by the Byzantine emperor. According to the Regesten des Oströmischen Reiches, a first delegation to Pippin is witnessed for $756^{59}$ in connection with the Ravenna matter and the restitution of the city to the Byzantine emperor. The next delegation followed in $757,{ }^{60}$ then in $763^{61}$ and $765 / 66^{62}$. The envoys always handed over a letter from the Byzantine emperor, but at that time the imperial chancery had long changed the language of the official documents from Latin to Greek (the turning point is around the end of the 6th and the beginning of the 7 th c.). ${ }^{63}$ The Greek documents were not accompanied by a Latin translation (at the Byzantine court) - the chancery in Constantinople did not start issuing bilingual letters until the late 9th c. (after the first preserved original document for the West, the "imperial letter of St Denis « ${ }^{64}$ for the Latin West maybe even some time later). The addressee was responsible for the translation of the text. A northern ruler without any Greek infrastructure might have been supported by a bilingual Italian translator who joined the imperial embassy (for example by order of the pope). We are not informed as to whether the imperial delegation offered a translation service to the addressee or if the addressee preferred to draw on his own or at least western translators to avoid "manipulations". It would make sense that the king of a new dynasty wanted to create his own (loyal) translator(s).

The second area which might have triggered some interest in the Greek language is the need to gain access to topics that are discussed in Greek and roused the interest of Frankish learned men. The best example is the Dionysius Areopagite translation about half a century later, a situational interest. In the Latin theological literature one is confronted with the need for some basic Greek knowledge, for example by reading the patristic authors Jerome or Augustine. Both make use of Greek terms in their commentaries on the Bible, which became the basics for medieval exegesis. A particular case is a chronological handbook I will

58 See also Schreiner, Begegnung; Schreiner, Zur griechischen Schrift (repr. in: Schreiner, Orbis Romanus 21-38).

59 Dölger, et al., Regesten 1, 1, Reg. 318.

60 Dölger, et al., Regesten, 1, 1, Reg. 320

61 Dölger, et al., Regesten, 1, 1, Reg. 322

62 Dölger, et al., Regesten, 1, 1, Reg. 325

63 See Gastgeber, Lateinische "Übersetzungsabteilung « 1, LX-LXXV.

64 Dölger, et al., Regesten, 1, 1, Reg. 413, in the revised second edition the letter is dated to May 427 according to a recent discussion in McCormick, La lettre diplomatique. This cannot be accepted as the final date beyond any doubt. Unfortunately, the editors did not explain why they believe this dating rather than other proposals, a. o. in the 40 . 
come back to in the next chapter. Against the background of theological debates, some Greek patristic authors focusing on topics being tackled anew in contemporary debates are further candidates for situational interest, if these texts became known to northern scholars and ever found their way north of the Alps. In hagiography the local worship of a saint, too, may have aroused interest in a Greek source if a translation was not already in circulation.

To illustrate the need for Greek basics in order to read patristic commentaries, I want to rely on two 8th c. manuscripts with commentaries by Jerome, both written in the monastery of St. Peter of Corbie and containing the Liber quaestionum hebraicarum in Genesim: Paris, BnF, ms. lat. 13347 and $13348^{65}$. In explaining the meaning of the passages Jerome also quotes Greek versions and inserts Graeca in Greek script, knowledge of which he could expect from his audience - but not in later times.
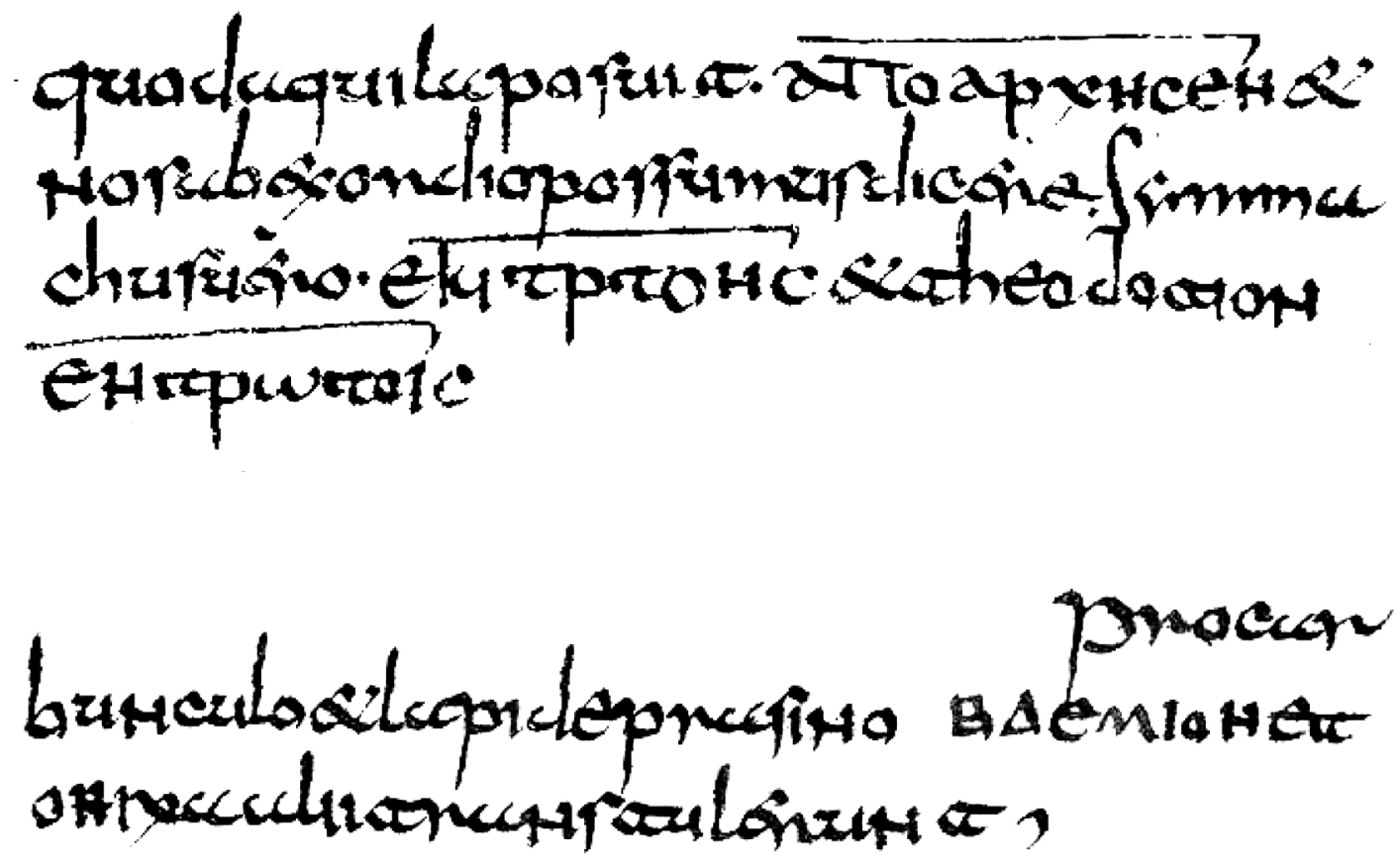

Figures $2 a$ and $2 b$ : Paris, BnF, ms. lat. 13347, f. $4 v$ (reproduction of the original script by the author)

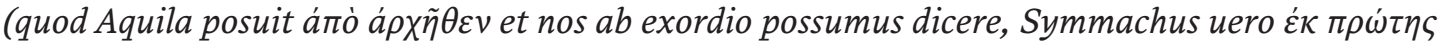

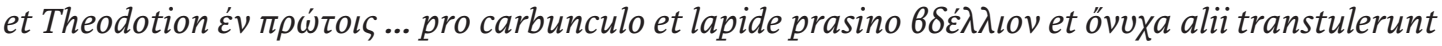
[ed. Lagarde, 5, 11. 2-4, 11-12])

65 Ganz, Corbie, 131; see also Bischoff, Katalog 3: Padua-Zwickau, 204, no. 4890a (only ms. lat. 13347 is included). 


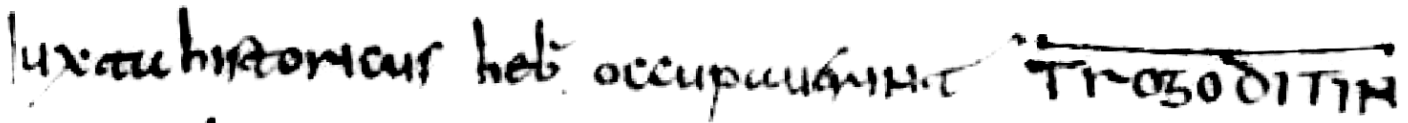

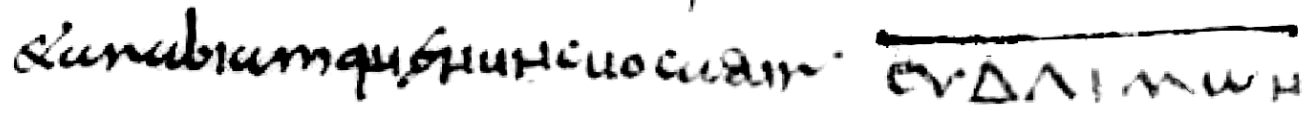

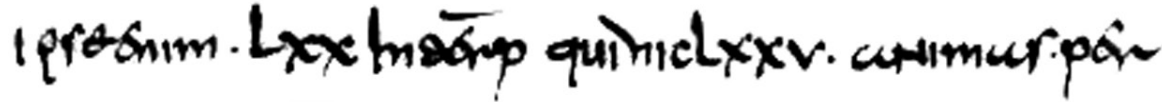 ITPOAHMXIH eumloropheporagurrur ccegripaim}

Figures $3 a$ and $3 b$ : Paris, BnF, ms. lat. 13348, ff. 25r, $40 \mathrm{v}$ (reproduction of the original script by the author)

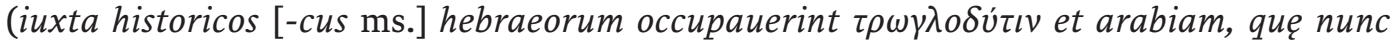

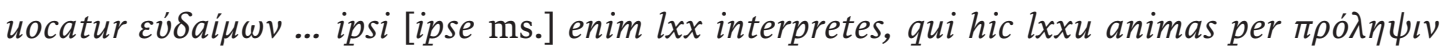
cum ioseph et posteris suis aegyptum ... [ed. Lagarde, 39, 11. 8-9; 63, 1. 31-64, 1. 1])

To pick out the Graeca ${ }^{66}$, it is evident that the inserted words followed a tradition of scribal errors, resulting from a lack of knowledge; the copies are products of the same monastery that was to become the leading institution for transmitting Greek texts to the Franks.

\section{Greek at the early Frankish court}

We can find traces of approaches to or even very active practising of Greek even before the new wave of learning Greek became part of the so called Carolingian Renaissance. ${ }^{67}$ Two translated texts were the focus of recent research: the Aratus latinus and the Excerpta latina Barbari.$^{68}$ The Aratus latinus was analysed in a monograph by Hubert Le Bourdellès ${ }^{69}$ concluding that the text was translated in the monastery of Corbie "avant la réforme carolingienne «, but, based on linguistic idiosyncrasies, after the Excerpta latina Barbari..$^{70}$ Since the Excerpta had not been subjected to a thorough analysis when Le Bourdellès dedicated his study to Aratus latinus, he based his dating of the Excerpta on mere linguistic aspects (in comparison with literary products in the monastery of St. Peter in Corbie) and dated it to around $700 .{ }^{71}$ He proposed a date for the Aratus latinus under the abbot Grimon (ca. 723-748) before the so called Carolingian Renaissance, which he believed to have already

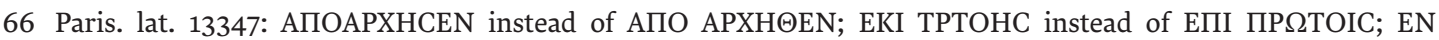
ПР $\Omega$ TOIC correct!; the two words of the second sentence are right (but itacistic ONIXA instead of ONYXA) if one was able to read the letters in their particular shape; Paris. lat. 13348: ТРОГО $\Delta \mathrm{ITIN}$ instead of TР $\Omega \Gamma \Lambda \mathrm{O} \triangle \mathrm{YTIN}$, $\mathrm{EY} \triangle \Lambda \mathrm{IM} \Omega \mathrm{N}$ instead of EY $\triangle \mathrm{AIM} \Omega \mathrm{N}$; ITPO $\triangle \mathrm{HMXIN}$ instead of ПPO $\Lambda \mathrm{H \Psi IN}$.

67 A (very) short overview about this time is provided in Boulhol, Connaissance, 30-34.

68 For a translation from Greek into Latin of the Apocalypsis of Ps.Methodius (a text originally written in Syriac ca. 690 AD) in the first third of the 8th c. in Southern France see Aerts and Kortekaas, Apokalypse 15-16, 19-35; according to the editors' linguistic analysis of the Latin version, the translator slavishly rendered the Greek into a typical Merovingian Latin.

69 Le Bourdellès, Aratus latinus.

70 See Le Bourdellès, Aratus latinus, 251-257 and 259-263, quotation on p. 259.

71 Le Bourdellès, Aratus latinus, 262. 
started under Pippin the Short in the years 750/60. Le Bourdellès describes the quality of this translator as follows: "Il est hors de doute que le traducteur est un Occidental qui n'a pas reçu l'aide d'un Oriental. Il commet en effet des bévues qu'un homme originaire d'un pays hellénophone n'aurait pu commettre, si même nous le supposons de culture très réduite ... Les pièges de l'iotacism ont fait souvent trébucher le traducteur qui ... manipulait dangereusement les doublets orthographiques représentant le même phoneme. Ces erreurs sont innombrables, et de tout ordre, mauvaise coupure entre les mots, mauvaise identification des mots, erreur sur le sens des mots, fautes d'interprétations sur les liens syntaxiques, etc. ... Dans ces conditions, on peut ajouter que les connaissances très imparfaites ne venaient pas du contact avec un Grec d'origine, car ce type de contact procure toujours une souplesse linguistique qui fait cruellement défaut à notre traducteur. Ces connaissances lui venaient donc de livres, grammaires et lexiques. ${ }^{72}$

The detailed research on the Excerpta latina Barbari by Richard Burgess ${ }^{73}$ proposed a significantly later date for the Excerpta. This work is a word-by-word translation of an illuminated Greek chronological handbook supplemented by a geographical part (diamerismos) and consularia. ${ }^{74}$ Burgess based his dating in the time of Abbot Maurdramnus (772-781) on palaeographic (»distinctive Maurdramnus script (75) $^{75}$ and provenience research on the codex unicus, Parisinus latinus $4884^{76}$; again, the translation is located in the monastery of Corbie. ${ }^{77}$ From his results it appears that the Aratus latinus as a "pre-Carolingian" and post-Excerpta translation must be dated around the last third of the 8th c. Hence, we come to a time of about 10-20 years after our letter. It is tempting to link one fact to the other, but we cannot be sure that Pippin really intended to strengthen a "Greek translation division" in Corbie. Nevertheless, Corbie was one of the few northern French monasteries which received the grant of immunity from Pippin (762) and Charlemagne (769); ${ }^{78}$ under the famous abbot Maurdramnus, whose name is linked to its own type of script, Charlemagne's cousin Adalhard entered the monastery in about 772 and became abbot there in $781 .^{79}$

72 Le Bourdellès, Aratus latinus, 136.

73 Burgess, Date.

74 It consists of the following parts (Burgess, Date, 7-8): 1) an interpolated and truncated version of the Liber generationis supplemented by a divisio terrae, 2) regnal lists based mainly on Julius Africanus' chronography and 3) consularia.

75 See Ganz, Corbie, 43, 133-134.

76 For the manuscript, see also Ganz, Corbie, 133-134 (Maurdramnus Script); Bischoff, Katalog 3: Padua-Zwickau, 104, no. 4343a (s. IX!)

77 Burgess, Date, 20-33; as mediator of the Greek original from Italy to the North, George, former bishop of Ostia and finally bishop of Amiens 767-798 (also a protegé of Pippin), is taken into consideration (however, not as the translator due to the quality of the Latin and translation errors); according to Burgess George was a Greek (Date, 23 »it is possible that he was a Greek from southern Italy ..., Sicily or the East «, 30 »George, who, as a Greek ...»), but in this regard his argumentation is not convincing (23: "George is a Greek name and rare in the West at this date $\lll)$.

78 See Ganz, Corbie, 21-22.

79 See Kasten, Adalhard; Depreux, Prosopographie, 76-79. 
Burgess provides a very illustrative analysis of the translator of the Excerpta as follows (p. 26) »Our translator obviously had been taught Greek as well as Latin, but he was no expert: we can observe basic errors of understanding the vocabulary, unusual verb forms, and construction; rigid, sometimes word-for-word translation ..., and the amateur translator's reliance on a fairly basic Greek-Latin glossary. His Greek would have been geared in the first instance toward reading the New Testament, with the ultimate goal of perhaps being able to read eastern imperial correspondence ... and other sophisticated works like letters and treatises of the eastern fathers and Ps.-Dionysius ${ }^{80}$, not Homer, Herodotus, or tragedy. ... a graduate research assistant struggling to translate Greek into Latin. ${ }^{81}$ The Excerpta impressively illustrate the aforementioned selection of texts: a handbook for biblical studies, one of the chronological lists in which (the Alban kings in Italy originating from Aeneas) was manipulated in order to incorporate a Frankish king into the early Roman genealogy: Francus Silvius, fourth successor of Aeneas. This insertion stands in the tradition of also relating the Franks to a Trojan origin and illegitimate succession. ${ }^{82}$

The panorama of an increasing interest in Greek as outlined above is furthermore witnessed by a bilingual manuscript of the Epistles of Paul (Paris, BnF, ms. gr. 107, 107A-B) from the second half of the 8th c., also written at the monastery of St. Peter in Corbie, ${ }^{83}$ and a Greek "starter « in codex Weissenburgensis 86 of the Herzog August Library in Wolfenbüttel, written in the monastery of St. Martin in Tours (mid-eighth c.?): ${ }^{84} \mathrm{ff} .145 \mathrm{r}-145 \mathrm{~V}$ comprise a Greek-Latin glossary entitled Esidori Iunioris Palestinensis episcopi gram(m)aticae artis nom(ina) greca et Latina notata, mainly based upon the Etymologiae of Isidore of Seville. The Graeca are here written exclusively in Latin transcription and in the same (pre-Carolingian) script as the Latin explanation. At the end of the manuscript two different scribes made use of the free space on ff. 216r-217r to add three Greek liturgical texts (scribe 1: f. 216rv Gloria, Magnificat; scribe 2, a bit better trained: f. 217rv Benedictus). But this part cannot be precisely dated as these unpractised scribes used an ink differing from the preceding Latin text and their timeless majuscule script reveals no hints for dating.

To summarise, the interest in Greek at that time is not comparable to modern language learning, i.e. to communicate in the learned language (and to be able to read any kind of texts in this language). The Frankish Greek students were interested in a selection of Greek texts and they realised that Greek was somehow necessary to understand the tradition of their own patristic - and classical, as far as they began to read pagan Latin authors - literature with quotations of Greek words and phrases. That some medieval scholars capable of using Greek

80 This author is mentioned with regard to the letter from Pope Paul I to Pippin III; see n. 44.

81 Burgess, Date, 25-26.

82 Burgess, Date, 33-38; on this topic, see Kippel, Darstellung; Ewig, Troiamythos.

83 Online presentation at the Gallica homepage of the Bibliothèque nationale de France, Paris. Retrieved on $12 \mathrm{Au}-$ gust 2018: gallica.bnf.fr/ark:/12148/btv1b84683111; not included in the list of Ganz, Corbie, but in Zechiel-Eckkes, Bestandsaufnahme. Retrieved on 12 August 2018 from the homepage of the Monumenta Germaniae Historica: www.mgh.de/datenbanken/leges/pseudoisidor/corbie/.

84 See Butzmann, Weissenburger Handschriften, 248-249; online presentation at the homepage of the Herzog August Library of Wolfenbüttel. Retrieved on 15 September 2018: diglib.hab.de/?db=mss\&list=ms\&id=86-weiss\&hi=86. 
wanted to excel with their exclusive competence and so provoked others to emulation, even an ostensive rather than real knowledge, is another aspect that naturally occurs in a society with gifted scholars. On the other hand, learning Greek was not promoted by the Byzantine emperor; Greek had no chance of becoming the lingua franca or of ousting Latin in the West.

As regards the importance of envoys as cultural brokers, this letter is a good example of how cultural export was executed, in this case by opening a path for the Franks to get acquainted with Greek and the respective literature. We must not be surprised that the Latin pope takes over this role of the Greco-Latin mediator. Rome looks back on a tradition of high Greek culture with a series of popes of Greek origin. ${ }^{85}$ However, it must be stressed that it was not the Byzantine court, which supported Pippin or vice versa, that Pippin asked to supply basic texts of the Greek language; his commitment to Greek is completely directed towards Rome without involving Byzantium.

85 See Ekonomou, Byzantine Rome (with detailed bibliography). 


\section{References}

Aerts, Williem J. and Kortekaas, Georgius A.A., Die Apokalypse des Pseudo-Methodius: Die ältesten griechischen und lateinischen Uebersetzungen, Corpus Scriptorum Christianorum Orientalium 570 (Louvain, 1998).

Becker, Gustav, Catalogi bibliothecarum antiqui (Bonn,1885).

Berschin, Walter, Greek Letters and the Latin Middle Ages from Jerome to Nicholas of Cusa. Revised and expanded edition, translated by Jerold C. Frakes (Washington, D.C., 1988).

Bischoff, Bernhard, Katalog der festländischen Handschriften des neunten Jahrhunderts (mit Ausnahme der wisigotischen), Teil 3: Padua-Zwickau. Aus dem Nachlass herausgegeben von Birgit Ebersperger (Wiesbaden, 2014).

Boulhol, Pascal, La connaissance de la langue grecque dans la France médiévale VIe-XVe s. (Aix-en-Provence, 2008).

Bruckner, Albert and Marichal, Robert, Chartae Latinae Antiquiores, part XVI: France IV (Zurich, 1986)

Burgess, Richard W., The Date, Purpose, and Historical Context of the Original Greek and the Latin Translation of the So-Called Excerpta Latina Barbari, Traditio 68 (2013) 1-56.

Butzmann, Hans: Die Weissenburger Handschriften, Kataloge der Herzog August Bibliothek Wolfenbüttel: Neue Reihe, vol. 10 (Frankfurt am Main, 1964). Online presentation on the homepage of the Herzog August Library of Wolfenbüttel, retrieved on 15 September 2018: diglib.hab.de/?db=mss\&list $=m s \& i d=86$-weiss\&hi $=86$.

Cameron, Margaret, Boethius on utterances, understanding and reality, in: John Marenbon (ed.), The Cambridge Companion to Boethius (Cambridge, 2009) 85-104.

Codex epistolaris Carolinus. Frühmittelalterliche Papstbriefe an die Karolingerherrscher, ed. Florian Hartmann and Tina B. Orth-Müller, Freiherr-vom-Stein-Gedächtnisausgabe 49 (Darmstadt, 2017).

Codex epistolaris, ed. Wilhelm Gundlach, Monumenta Germaniae Historica, Epistolarum III, Merowingici et Karolini aevi I (Berlin, 1892).

Codicis Carolini epistolae, ed. Philipp Jaffé, Bibliotheca Rerum Germanicarum IV, Monumenta Carolina (Berlin, 1867).

Crisci, Edoardo, La maiuscola ogivale diritta. Origine, tipologie, dislocazione, Scrittura e Civiltà (1985) 103-145.

Depreux, Philippe, Prosopographie de l'entourage de Louis le Pieux (781-840), Instrumenta 1 (Sigmaringen, 1997).

Devreesse, Robert, Le fonds grec de la Bibliothèque vaticane des origines à Paul $V$, Studi e Testi 244 (Vatican, 1965)

Dickey, Eleanor, Ancient Greek Scholarship. A Guide to Finding, Reading, and Understanding Scholia, Commentaries, Lexica, and Grammatical Treatises, from Their Beginnings to the Byzantine Period (Oxford, 2007).

Dölger, Franz, Müller, Andreas E., Preiser-Kapeller, Johannes, and Riehle, Alexander, Regesten der Kaiserurkunden des Oströmischen Reiches von 565-1453, 1 Teil, 1. Halbband: Regesten 565-867 (Munich, 2009).

Dümmler, Ernst, Reply to review of Codex epistolaris by Paul Kehr, Neues Archiv der Gesellschaft für ältere deutsche Geschichtskunde 19 (1894) 475-477.

Ekonomou, Andrew J., Byzantine Rome and the Greek Popes, Eastern Influences on Rome and the Papacy from Gregory the Great to Zacharias, A. D. 590-752 (Lanham, 2007). 
Erismann, Christophe, On the Significance of the Manuscript Parisinus graecus 437. The Corpus Dionysiacum, Iconoclasm, and Byzantine-Carolingian Relations, in: Falko Daim, Christian Gastgeber, Dominik Heher and Claudia Rapp (eds.), Menschen, Bilder, Sprache, Dinge. Wege der Kommunikation zwischen Byzanz und dem Westen 2: Menschen und Worte, Byzanz zwischen Orient und Okzident 9,2 (Mainz, 2018) 95-101.

Ewig, Eugen, Troiamythos und fränkische Frühgeschichte, in: Dieter Geuenich (ed.), Die Franken und die Alemannen bis zur »Schlacht bei Zülpich « (496/97), Ergänzungsbände zum Reallexikon der germanischen Altertumskunde 19 (Berlin, 1998) 1-30.

Ganz, David, Corbie in the Carolingian Renaissance, Beihefte der Francia 20 (Sigmaringen, 1990).

Gastgeber, Christian, Die lateinische "Übersetzungsabteilung" der byzantinischen Kaiserkanzlei unter den Komnenen und Angeloi. Unpublished PhD Thesis, 3 vols. (University of Vienna, 2001).

Gundlach, Wilhelm, Über den Codex Carolinus, Neues Archiv der Gesellschaft für ältere deutsche Geschichtskunde 17 (1892) 527-566.

Hack, Achim Thomas, Codex Carolinus. Päpstliche Epistolographie im 8. Jahrhundert, 2 vols, Päpste und Papsttum 35, 1-2 (Stuttgart, 2007).

Hunger, Herbert, Die hochsprachliche profane Literatur der Byzantiner, 2. Band, Handbuch der Altertumswissenschaft XII 5, 2 (Munich, 1978).

Irigoin, Jean, La culture grecque dans l'occident latin du VIIe au XIe siècle, in: La cultura antica nell'occidente latino del VII all'XI secolo, Settimane di studio del Centro italiano di studi sull'alto medioevo 22 (Spoleto, 1975) 425-446.

Jaffé, Philipp, Regesta Pontificum Romanorum, tomus secundus (ab a. DCIV usque ad a. DCCCXLIV), revised edition by Klaus Herbers, Waldemar Könighaus, Thorsten Schlauwitz, Cornelia Scherer and Markus Schütz (Göttingen, 2017).

Kaczynski, Bernice M., Greek in the Carolingian Age. The St. Gall Manuscripts, Speculum Anniversary Monographs 13 (Cambridge, Massachusetts, 1988).

Kasten, Brigitte, Adalhard von Corbie. Die Biographie eines karolingischen Politikers und Klostervorstehers (Düsseldorf, 1986).

Kehr, Paul, Codex epistolaris, ed. Wilhelm Gundlach. Reviewed in: Göttingische Gelehrte Anzeigen 22 (1893) 871-898.

Kehr, Paul, Ueber die Chronologie der Briefe Pauls I. im Codex Carolinus, Nachrichten von der Königl. Gesellschaft der Wissenschaften, philologisch-historische Klasse (1896) 102-157.

Kippel, Maria, Die Darstellung der Fränkischen Trojanersäge in Geschichtsschreibung und Dichtung vom Mittelalter bis zur Renaissance in Frankreich (Marburg, 1936).

Le Bourdellès, Hubert, L'Aratus latinus. Étude sur la culture et la langue latines dans le nord de la France au VIIIe siècle (Lille, 1985).

Leuven Database of Ancient Books, co-ordinated by Willy Clarysse. Retrieved on 12 August 2018: www.trismegistos.org/ldab/index.php.

Lilie, Ralph-Johannes, Ludwig, Claudia, Zielke, Beate and Pratsch, Thomas, Prosopographie der mittelbyzantinischen Zeit. Retrieved on 29 August 2018: www.degruyter.com/view/ $\mathrm{db} / \mathrm{pmbz}$.

Loenertz, Raymond-Joseph, La légende Parisienne de s. Denys l'Aréopagite. Sa genèse et son premier témoin, Analecta Bollandiana 69 (1951) 217-238. Reprinted in Loenertz, Raymond-Joseph, Byzantina et Franco-Graeca, Storia e Letteratura 118 (Rome, 1970) 163183.

Marenbon, John, Boethius (Oxford, 2003). 
McCormick, Michael, La lettre diplomatique byzantine du premier millénaire vue de l'Occident et l'énigme du papyrus de Paris, in: Michel Balard, Élisabeth Malamut, Jean-Michel Spieser (eds.), Byzance et le monde extérieur. Contacts, relations, échanges, Actes de trois séances du XXe Congrès international des Études byzantines, Paris, 19-25 août 2001, Byzantina Sorbonensia 21 (Paris, 2005) 135-149.

Nürnberger, August, Die Bonifatiuslitteratur der Magdeburger Centuriatoren, Neues Archiv der Gesellschaft für Ältere Deutsche Geschichtskunde zur Beförderung einer Gesamtausgabe der Quelleninschriften deutscher Geschichte des Mittelalters 11, 1 (1886) 11-41.

Orsini, Pasquale, La maiuscola ogivale inclinata: contributo preliminare, Scripta 9 (1026) 89-116.

Orth-Müller, Tina, Philologische Studien zu den Papstbriefen des »Codex epistolaris Karolinus", Lateinische Sprache und Literatur des Mittelalters 47 (Bern, 2013).

Paris, Bibliothèque nationale de France, ms. lat. 13347. Retrieved on 12 August 2018: gallica. bnf.fr/ark:/12148/btv1b84683111.

Pinakes Database, CNRS, Paris. Retrieved on 12 August 2018: pinakes.irht.cnrs.fr/.

Pontificum Romanorum Diplomata papyracea quae supersunt in tabulariis Hispaniae, Italiae, Germaniae (Vatican, 1929).

Rabikauskas, Paul, Die römische Kuriale in der päpstlichen Kanzlei, Miscellanea Historiae Pontificiae 2 (Rome, 1958).

Ronconi, Filippo, Quelle grammaire à Byzance? La circulation des textes grammaticaux et son reflet dans les manuscrits, in: Giuseppe De Gregorio (ed.), La produzione scritta tecnica e scientifica nel Medioevo: libro e documento tra scuole e professioni. Atti del Convegno internazionale, Fisciano-Salerno, 28-30 settembre 2009 (Spoleto, 2012) 63-110.

Sansterre, Jean-Marie, Les moines grecs et occidentaux à Rome aux époques byzantine et carolingienne (milieu du VIe s.-fin du IXe s.)' vol. 1: texte, Académie Royale de Belgique. Mémoires de la classe des lettres, 2e ser., tom. 66, 1 (Bruxelles, 1983).

Schreiner, Peter, Die Begegnung von Orient und Okzident in der Schrift, in: Erika Juhász (ed.), Byzanz und das Abendland: Begegnungen zwischen Ost und West, Antiquitas-ByzantiumRenascentia 5, Bibliotheca Byzantina 1 (Budapest, 2013) 11-41.

Schreiner, Peter, Orbis Romanus, Byzanz und seine Nachbarn (Bucharest, 2013).

Schreiner, Peter, Zur griechischen Schrift im hochmittelalterlichen Westen: Der Kreis um Liutprand von Cremona, Römische-Historische Mitteilungen 45 (2003) 305-317 (= Schreiner, Orbis Romanus, 21-38)

Sickel, Theodor, Review of Codicis Carolini epistolae, ed. Philipp Jaffé, Historische Zeitschrift 19 (1868) 182-190.

Théry, Gabriel, Études Dionysiennes 1: Hilduin, traducteur de Denis, Études de philosophie médiévale 16 (Paris, 1932).

Unterkircher, Franz, Codex epistolaris Carolinus. Österreichische Nationalbibliothek Codex 449, Codices selecti 3 (Graz, 1962).

Vienna, Austrian National Library, cod. 449. Retrieved on 12 August 2018: data.onb.ac.at/ $\mathrm{rec} / \mathrm{AC} 13951168$.

Wolfenbüttel, Herzog August Library, cod. Weissenburgensis 86, Retrieved on 12 August 2018: diglib.hab.de/?db=mss\&list $=m s \& i d=86$-weiss\&hi=86.

Zechiel-Eckkes, Klaus, Handschriften aus Corbie (bis 850). Eine Bestandsaufnahme. Retrieved on 12 August 2018: www.mgh.de/datenbanken/leges/pseudoisidor/corbie/. 


\section{List of figures}

Figure 1: Vienna, Austrian National Library, Cod. 449, f. 36r (part of the embolum) with the corrections by the Viennese librarian Sebastian Tengnagel (c/o ÖNB, Vienna)

Figures 2a and 2b: Paris, BnF, ms. lat. 13347, f. 4v (reproduction of the original script by the author)

Figures 3a and 3b: Paris, BnF, ms. lat. 13348, ff. 25r, 40v (reproduction of the original script by the author) 